\title{
Mixed Signals: How German Lieder, as Multimodal Texts, Present Particular Challenges for Translators
}

The Lied (art song) is a fusion of poetry and music and according to some, this fusion is impossible to translate: can a song composed of the rhythms, sounds, rhymes and meaning of one language ever be represented satisfactorily in another? Here, however, I will provide a more optimistic picture by addressing the following questions: how does a translator manage the inter-relationship between the acoustic codes of music and the verbal codes of poetry and does the overriding Skopos of creating a singable translation necessarily jeopardize the poetical qualities of a song?

Lieder are songs based on poems, composed mainly in the $19^{\text {th }}$ century and usually written for a single voice with piano accompaniment. The poems were usually independent works before being set to music. Of the many composers of German Lieder, Franz Schubert, is often credited with having made the Lied the art form we know today (Dahlhaus 1991: 96). What distinguishes Schubert's compositions is his use of modulation ${ }^{1}$ and chromatics ${ }^{2}$ to introduce drama and psychological tension and his deviance from the standard four-bar period to variable phrasing, which creates closer connections between the poem and the music.

To discuss how the inter-relationship between the acoustic codes of music and the verbal codes of poetry influence the translation of vocal music, I shall draw on translations of Schubert's $1815^{3}$ strophic song Erlkönig D328 $^{5}$, based on a poem of the same name by Goethe (1782: 89)

${ }^{1}$ Modulation is the process of changing from one key note to another.

${ }^{2}$ Chromaticism is an alteration of or deviation from the basic diatonic organization. It is used expressively and structurally to modulate to a different key.

${ }^{3}$ Composed 1815 first published 1821.

${ }^{4}$ Usually translated as Erlking, but sometimes also as Elf King or Alder King.

${ }^{5}$ To view a score visit IMSLP: http://imslp.info/files/imglnks/usimg/b/b2/IMSLP15038SchubertD328_Erlk\%C3\%B6nig_1st_version.pdf [accessed Jan. 15, 2014]. 
written in 1782. The poem is in ballad form comprising eight stanzas, each of four lines. The rhyme scheme is aabb and the poem is written in iambic tetrameter, with frequent use of anapaests, which are generally taken as representing the sound of a horse galloping. The poem is a horror story of sorts: a narrator begins by describing a father's frantic ride home on horseback, through the woods, holding his child. The frightened child, who appears to be hallucinating, tells his father that he sees a supernatural spirit, the Erlking. The father tries to allay the child's fears by giving rational explanations for the uncanny visions and events, which the child relates to him. The Erlking attempts to lure the child away to his kingdom with promises of good things that await him there and despite the child's call to his father for protection, the Erlking prevails and takes him by force. At the end of the poem, the father arrives home with his son dead in his arms.

There are just three published singable translations of Erlkönig, published over a period of some one hundred years from the late $19^{\text {th }}$ century to the $1980 \mathrm{~s}$. The earliest is by the American translator Theodore Baker, whose translation The Erlking was published in 1895 (Schubert 1895: 214-221). The second is by Sir Robert Garran, an Australian who published his translation Erl-King in 1946 (Garran 1946: 133). The third is by Leslie Minchin (d.1999), whose translation The Erl-king was published in 1982 (Minchin 1982: 40).

The translation of Lieder may be considered in the wider context of multimodal translation in which careful consideration is given to the integration and interaction of a number of modes of communication or semiotic systems. To define this integration, pioneers of research into multimodality (Kress and van Leeuween; O'Toole) drew on Halliday's social semiotic approach to language, which models the meaning potential of words, sounds and images as sets of inter-related systems and structures (Language). In translation studies, Reiss similarly drew attention to the importance of the "'additional information' supplied by a sign system other than that of language" to supplement the translation of a multimodal text (Reiss 1981: 125) and Snell-Hornby's "integrated approach" to translation drew on Gestalt theory (Snell-Hornby 2006: 445), suggesting that since the whole is always more than the sum of the parts, translation of multimodal texts requires consideration of the "web of relationships" of its constituent parts (ibid.: 450). Translation of a multimodal text requires of the translator the ability to process all the sign systems in the text, especially the interplay between them, which impose on the translator's choices and strategies (Mayoral et al. 1988: 362). 
The Lied combines two sign systems or modes: music and poetry. The musical mode is, in Jakobson's terms, already an act of intersemiotic translation (Jakobson 1960: 139); an interpretation of a poem by the composer. The Lied presents the two modes to the same sense, the ear. Cognitively the listener must process two inputs at once: poetry and music. The inputs may effectively duplicate meaning and create cognitive overload unless the combination is a blend, sharing elements to avoid competing for signification. The composer has the task of creating this blend and is able to do so because the two modes of meaning, poetry and music, with which he works, share a number of attributes that enable them to form an interrelationship; what they especially share is the paradigmatic and syntagmatic relationship that constitutes the poetic, as described by Jakobson (1960: 356). In other words, that which makes words into poetry, notes into music and their combination into song is their arrangement, relationship, connection or interplay, which the composer chooses to create, semantically, phonetically and rhythmically.

The complex nature of the Lied as an object of translation is highlighted by Gorlée (see for example, Intercode Translation) when she describes in Peircean terms how the verbal meaning of the poem is potentially changed by the composer's intersemiotic transfer of it into music. Peirce's triadic approach to the sign helps to explain this change (Peirce: 2.302). The object of the sign is some meaning or idea that the poet has conceived and wishes to communicate; the sign or representamen is the poem and the song composition is the interpretant sign. For the translator, it is important to understand that the "relationship between poetry and music is based upon the manner in which the poetic representamen determines a lyrical interpretant that exhibits the same relation to the [...] object as does the poetic representamen" (Mosley 1994: 415). This interpretant sign is an "equivalent yet more developed sign" (ibid.: 414) and one which in turn will go on to be further developed by the singer and ultimately the audience. Of course, the music and the poem have meaning within their own paradigms but the song is the combination and the object of translation. This would suggest that the goal of a translation must be to exchange the linguistic elements without creating any disjunction in the triadic relationship. In other words, the singer's interpretation should be able to remain the same, the audience should ideally experience the effect of the song (emotional and intellectual) in the same way as an audience hearing the original song.

However, all too often in vocal music translations, the complex intersemiosis of words and music cedes precedence to the undeniably exigent factors of fitting new words to the rhythm of the existing music, 
retaining rhymes, and ensuring that the singer can produce the sounds of the new words on the notes on which they are placed. This is highly understandable for when new words do not fit the musical rhythms and stresses, a song effectively becomes difficult, if not impossible, to sing, regardless of all other factors. It is, therefore, not surprising that most scholars in the field agree that rhythmic fit is a fundamental and nonnegotiable norm.

In translation terms, poetic metre can be flexible and the translator is "relatively free" to do with it as he pleases (Nida 1964: 177) but music fixes poetic metre in a rigid system and the "assertiveness" of music's "fixed elements" are "psychologically greater" than any exerted by the poem (Stein 1971: 12). Metrical or rhythmic fit between words and music may be thought of in terms of syllabic quantity, stress and length. Translations that match the original syllabic quantity are, as Low points out, the most desirable (Low 2005: 197). Achieving this, however, is extremely challenging. The demands of comprehension and the grammar of a language often entail additions or subtractions. Additional syllables can be discreetly accommodated when a note is split or another added or when tied notes are untied. Fewer syllables can be dealt with by combining or deleting notes or creating a melisma. ${ }^{6}$ Modest adjustments may have an imperceptible effect on the music, but some changes may compromise or even alter the musical meaning. For example, Lieder are characterised by a tendency to avoid melismas with composers generally setting one syllable to one note (Stein and Spillman 1996: 59) and where a melisma occurs it often plays a particularly expressive role. Baker's translation in bars 67 to 70 has only one extra syllable compared to the source text, but his translation has a different stress pattern that can only be made to fit the notes by adding and removing melismas. Where Schubert set the word "Mutter" to two notes, Baker sets his translation "mother" over four notes by tying notes together for each of the two syllables. Baker then accommodates five syllables in the third bar, where Schubert had only three, by untying the minim and the following two semi-quavers, thus removing the melisma, and creating a more articulated phrase with a syllable to each note. The way in which "mother" is set affects the singer's vocal production but not the meaning. However, in bar 69 Schubert's semantic intentions are potentially compromised. The melisma contributes to meaning by emphasising "gülden" (golden) as part of the Erlking's cajoling enticements in his initial attempt to lure away the child. The melisma also enhances the lyricism of the music, sweetly masking the

\footnotetext{
${ }^{6}$ A group of notes sung on one syllable.
} 
Erlking's evil desires. In Baker's translation, the corroborative meaning provided by the music is lost when the melisma is removed and the notes married to the perfunctory words "many a robe".

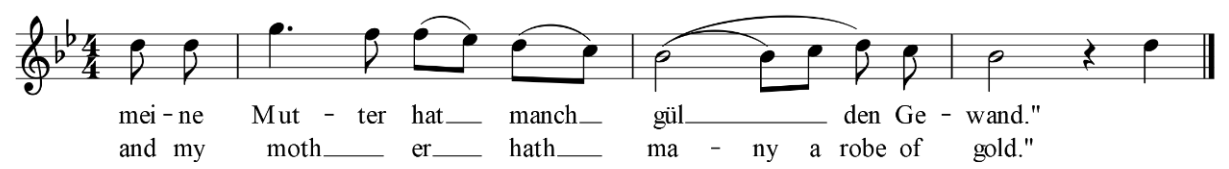

Figure 1. Franz Schubert, "Erlkönig” (D328), bars 67-70. Trans. Theodore Baker (Schubert 1895: 214-221)

Perhaps what is more important than syllabic quantity is syllabic stress. In music, the strongest stress is on downbeats such as the first beat of a bar. The composer will usually compose so that the natural stress of a word falls on a downbeat. Failure to match the stressed syllables in the translation to the stresses in the music usually renders it difficult, if not impossible to sing. One of the biggest challenges to achieving correct syllabic stress when translating from German to English is German's greater abundance of polysyllabic words that often forces the use of additional incidental words in the translation. Another challenge is German's frequent light syllabic " $\mathrm{e}$ " or "en" at the end of a word. An example of the latter can be seen in bars 23 to 27. In English, most equivalents for "Knaben" (boy) have only one syllable and so must either be moved elsewhere in the phrase and another word with two syllables (Minchin) set in its place, or it may be kept but followed by another onesyllable word which is unstressed (Baker and Garran):

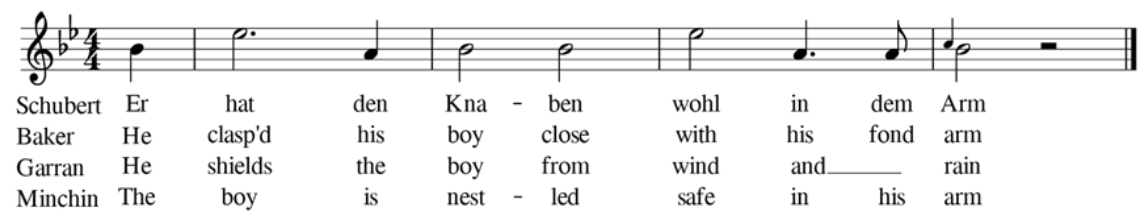

Figure 2. Franz Schubert, "Erlkönig” (D328), bars 23-27. Trans. Theodore Baker (Schubert 1895: 214-221), Garran (1946: 133), Minchin (1982: 40)

Baker's use of "close" is problematic because in speech, we expect it to be stressed and here it is set on the less stressed of the two notes. This is exacerbated by Baker setting "with" on a minim downbeat and diminished seventh chord. In the original song this chord serves to undermine the meaning of "wohl" (surely), now its irony is lost on a mere function word. 
Syllables can be short or long, usually determined by the vowel length. When a short syllable is set on a long note or vice versa, the line will be awkward to sing and sound unnatural. In bars 35 to 39, Baker translates "Mein Sohn, was birgst du so bang dein Gesicht?" as "Dear son, what makes thy sweet face grow so white?" There is a problem with the choice of the word "sweet" for its long vowel exacerbated by the combination of an assonant " $\mathrm{s}$ " and " $\mathrm{w}$ " must be sung on a short, unstressed quaver. It is difficult to sing and to hear and so the semantic potential of this phrase is compromised.

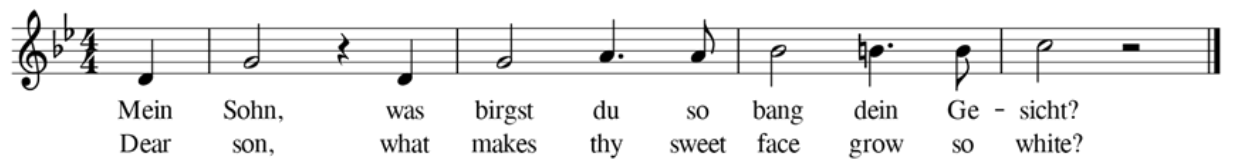

Figure 3. Franz Schubert, "Erlkönig” (D328), bars 35-39. Trans. Theodore Baker (Schubert 1895: 214-221)

The priority given to matching syllable count, stress and length inevitably means that translators compromise in other ways. In the 212 translations of Erlkönig, these compromises are inverted word order, archaic language (early modern English) and unusual grammar. Garran's archaic English gave him permission to produce phrases such as "And faintly was moaning the boy $[\ldots]$ ". This ignores the modern English placement of subject, verb and adverb. The archaic second person singular verb forms were extremely useful to him when translating from highly inflected German as they offer more syllables with which to work and provide a solution when translating the many lightly stressed verb or noun endings, for example, "My son why hidest thy face as in fear?" (Garran 1946). In archaic English, the periphrastic "do" can be abandoned, especially in questions, by using verb-subject inversion instead: for example, "[...] seest thou not then / the Erlking's daughter [...]?" (Garran 1946). Alternatively, the deliberate use of the auxiliary verb "do" can provide an additional syllable when needed: "Where my beauteous daughter doth wait for thee" (Schubert 1895). Archaic language also permits omissions of the pronoun, which we would otherwise expect in modern English: "Thou dearest boy, wilt come with me?" and "Wilt come, proud boy [...]" (Schubert 1895). The use of archaic contraction is also useful for reducing syllable count such as Baker's "Mong (contraction of among) wither'd leaves [...]" and the use of "'tis". Despite the modern English of Minchin's translation, he 
uses this three times. The use of unusual grammar can also reduce syllable quantity where this is desired as Garran demonstrates with "whispering soft in my ear", where he dispenses with the usual adverbial ending.

Such "tweaking" is often unavoidable (Low 2005: 197) when translating a song to be sung but whilst rhythmic fit is considered an essential requirement, so also is consideration of vocal production. Translations that pay little attention to vowels and consonants in relation to tempo and pitch may be difficult to sing and hard to understand.

There are two parts to the voice in singing: the expressive, musical element, which requires accurate, sustained vowels and the communication of speech, which needs well-defined consonants. The issue with vowels stems from the fact that certain vowels inhibit resonance because they prevent the shape and size of the oral cavity from being at its optimum for good tone. This becomes particularly problematic when singing in the very high or low range as the raising of the soft palate to sing certain notes makes it impossible to create certain vowel sounds easily. Singers, therefore, prefer "open vowels" on high and low notes when the tongue can remain flat and the vocal cavity has the right shape for perfect resonance. Vowel sounds that can cause problems on high or low notes are closed vowels such as " $\mathrm{u}$ " (as in "soon") and " $\mathrm{i}$ " (as in "see"). Of course, it is not always possible to avoid closed vowels and make sense and singers are used to modifying vowel sounds to save the voice and avoid harsh sounds. The drawback is that the word may not be clear. If it is a repeated word, there is no problem, but should the meaning of the phrase rely on hearing the word, the translator may want to consider finding a word with a more open vowel.

Consonants can be a threat to the beauty of sound. They close the mouth, tense the tongue and prevent airflow, all essential for tone quality. Singers prefer consonants that do not require the jaw to close as this changes the shape and size of the oral cavity and restricts good tone. For the same reason, consonant clusters are to be avoided especially in fast passages where they can create tongue twisters. Such clusters often result from the use of compound nouns, polysyllabic words, and words that start with the same consonant as that with which the previous word ended. Care must also be taken in the choice of consonants or consonant clusters set on very high notes. In such cases, the singer will make the consonant as short as possible and move quickly to the vowel, thus reducing audibility of the word. Composers who write for the voice tend to avoid placing an important word in such a position, unless it 
has been heard before at a lower pitch and the high pitch repetition is to show off the voice.

In the translations of Erlkönig there are very few challenges for the singer in terms of vowels or consonants with perhaps the exception of some setting of short vowels on long notes and long vowels on short notes as discussed above and consonant clusters such as "child closer clasp" (Baker) and "reaching to clutch" (Minchin). Other consonantal difficulties arise from the use of the archaic language forms "wilt come", "dids't", "can'st", "thou'rt" (Baker and Garran). The reason there are few vocalisation issues, is that in Erlkönig, as in many Lieder, the vocal range is narrow, there are no virtuosic wide set interval leaps and very high or low notes repeated numerous times.

Whilst a concern for vocal production and rhythmic fit are essential requirements that make a song singable or not, this cannot so easily be said for rhyme. Yet much ink has been dedicated to rhyme in the translation of vocal music. The desire to produce a rhyming song translation has often been blamed for strange lexical choices and incomprehensible language engendered by inverted word order and tortured syntax. Nearly everyone who has written on the matter seems inclined to agree that rhyme is a luxury that should be sacrificed in favour of sense and naturalness. Although rhyme gives structure to poems and joins thoughts phonetically and although it is often incorporated in the poem's musical interpretation, where it can be made more prominent, it has been said that music often makes rhymes "enfeebled and imperceptible" (Peyser 1922: 360). The auditory effect of rhyme in song is much weaker than in poetry because of the extended time between rhymes; the cadential function of rhyme is also replaced by musical cadence. Whilst in poetry, rhyme is an organisational element, in a song the music gives overall shape and structure. On the question of whether to rhyme or not, Low (2008: 6) suggests a translator ask questions about the frequency and importance of rhymes since a variable rhyme scheme combined with the musical space that is between them may mean that it is possible to avoid rhymes completely. I suggest, however, that it is also necessary to consider whether the musical structure or any musical features are closely connected to the rhymes, because musical rhymes (recurrent phrases, for example) may contribute to the significance of the words and, therefore, require that the translated words also rhyme. It is also worth remembering that rhyme is particularly helpful for the singer who often sings from memory! 
The three translators of Erlkönig adhere to the source text rhyme scheme of aabb for good reason: the rhymes are regular and frequent and are often evident in the musical structure. Sometimes rhymes have been set on musical recurrences related to pitch and duration:
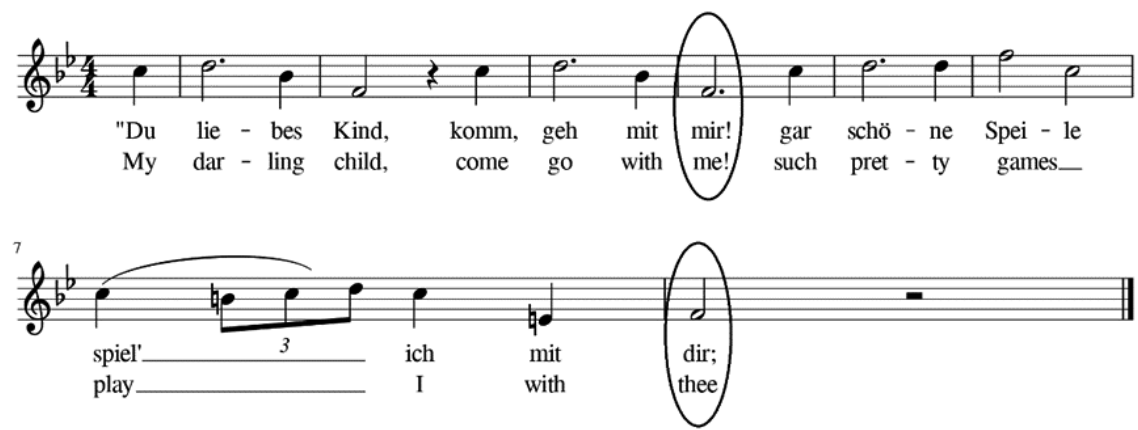

Figure 4. Franz Schubert, “Erlkönig” (D328), bars 55-63. Gloss translation

Sometimes these musical recurrences make the original rhyme stronger than in the poem. The words "gehen" (go) and "schön" (patiently) form an imperfect rhyme, sharing only the final consonant; the music strengthens their connection through the repeated musical intervals of a sixth (first major then minor):
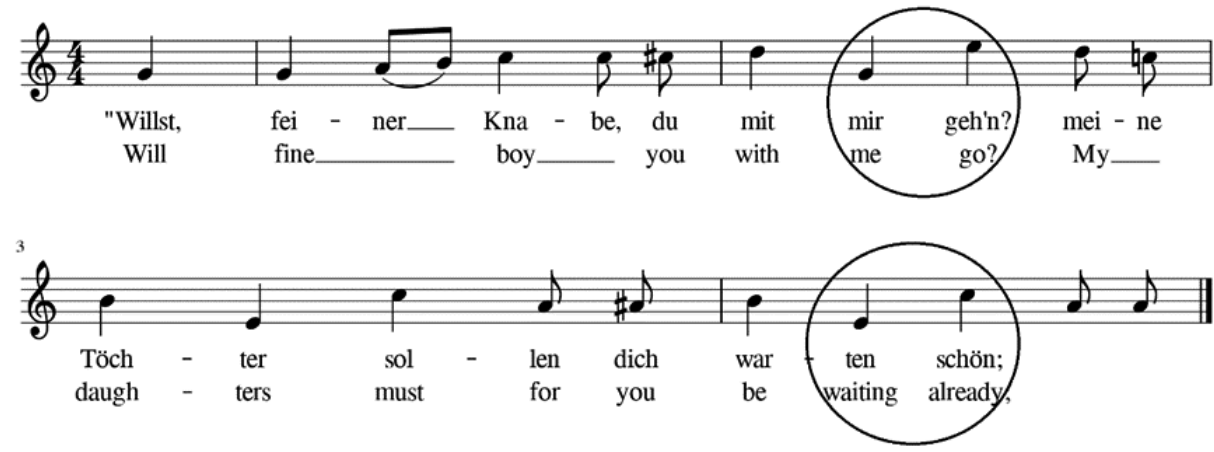

Figure 5. Franz Schubert, “Erlkönig” (D328), bars 83-87. Gloss translation

Rhyme's overriding importance in Erlkönig seems to have forced the translators to accept word order inversions, ellipsis, archaic syntax, unusual lexis, strange grammar and the use of paraphrase in order to reproduce it. The translations of the first line of the poem provide good examples of word order inversion in the service of rhyme: 
“Wer reitet so spät durch Nacht und Wind? / Es ist der Vater mit seinem Kind"

(Gloss: Who rides so late through night and wind? / It is the father with his child).

The word "Kind" (child) is of utmost importance given the subject matter of the poem, all the possible translations in English other than "child", such as "boy", "lad", "infant" or "baby" have problems in terms of register, cohesion or syllabic count. Whilst "son" is possible, its use by the father character in the direct speech sections of the poem makes it a less desirable option here. The translator is therefore forced to use the word "child" and must find a word that rhymes with it. The three translators chose "wild", which in each case modifies the noun "night" and communicates that it was windy. In modern English, the adjective would come before the noun, but in order to create a rhyming couplet it is placed after it:

Who rides there so late through night so wild?

A loving father with his young child

(Baker)

Who rides out so late this midnight wild?

It is a father who holds his child

(Garran)

Who gallops so fast through night so wild?

It is a father who clasps his child

(Minchin)

Baker's archaic English style gave him permission to freely resort to inverted word order in order to create a rhyming text. Consider "Dear son, dear son, the form you there see / Is only the hollow grey willow tree" and "Oh father! My father! thy child closer clasp / Erlking hath seiz'd me with icy grasp!" In modern English, the placement of adverbs of place and manner is usually after the verb. Minchin, for the sake of rhyme, is content with the use of unusual grammar. In the line "My father, my father, he's reaching to clutch / Now I am feeling his icy touch", he ignores the usual transitivity of the verb "to clutch". Garran also bends grammatical rules for rhyme as in "My son, my son, I see very clear / The old willow gleaming grey by the mere", which ignores the normal ending for adverbs.

However, the most interesting rhyme choices in Erlkönig occur in the following bars when the translators attempt to reproduce the "Gestalt/ Gewalt" (form/force) rhyme: 

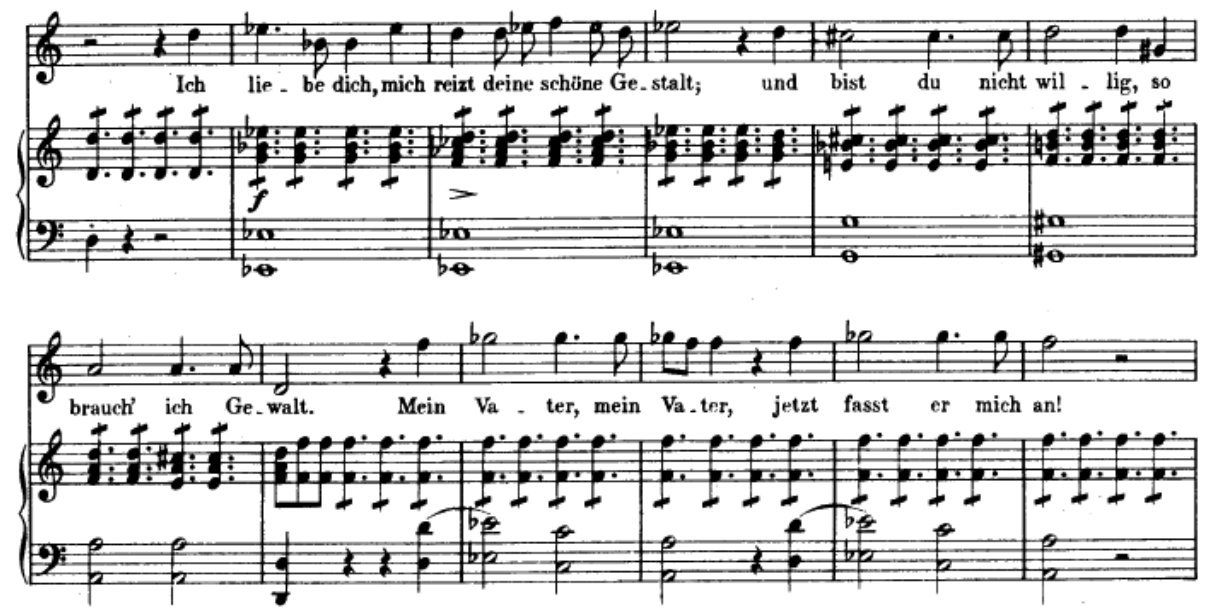

Figure 6. Franz Schubert, “Erlkönig” (D328), bars 113-124

There is an imperative that whatever replaces "Gewalt" (force) also translates the violence in the music, which sees the Erlking move from his cajoling major keys to the father and son's world of D minor. Baker and Minchin decided in favour of "force" which led them to the rhyming word "course", albeit with different meanings:

I love thee well, with me thou shalt ride on my course,

And if thou'rt unwilling, I seize thee by force!

(Baker)

I love thee child and now there is no other course

For if you're not willing, I'll take you by force

(Minchin)

Both translations convey the sense of impending doom, which is coherent with the rest of the poem. However, for the sake of rhyme they both fail to translate part of the first line: "mich reizt deine schöne Gestalt" (Gloss: your beautiful form excites/stirs me), which is the only place in the poem that a reason of any kind is given for the Erlking's desire for the boy. Garran, however, who retains the meaning through "thy beauty enraptures my sight", struggles to find a translation for "Gewalt" that rhymes with "sight". His solution is linguistically odd though perhaps not completely incomprehensible: "I love thee child thy beauty enraptures my sight/And if thou'rt unwilling, I'll take thee despite!" (Garran).

Rhyme, rhythm, and a concern for vocal production are important when creating a singable translation, but may not be enough to guarantee a "performable" translation that can be performed as authentically as the 
original song. The fusion of music and words requires the translator to think about how and what the music communicates. What is required is to try to discern how the composer interpreted the words as music. Understanding musical language is, therefore, another part of the hermeneutic endeavour necessary to understand the source text before attempting to translate it into another language.

When music is joined with words, it might iterate, corroborate, emphasise or contradict them, it might introduce irony or ambiguity, add information or expound on an idea, direct thoughts, give order to ideas, ask the listener to question or doubt the words, change perspective or mood, recall an earlier idea or associate a present thought with an earlier one. Music can do all this with musical codes that are based on cultural agreement, developed over hundreds of years, some of it available to everyone, some only to those who have learned the code in more depth and detail. There are two possible ways that music manages this communication: through a literal setting of the text also known as word painting and a dramatic setting of the text (Brown 1948: 71). In word painting, music tries to imitate the emotion, action, or natural sounds as described in the text. It seeks to illustrate the text. At its most basic, sad words and ideas might be set in a minor key and happy ones in a major key. The dramatic setting, however, whilst not devoid of literal interpretations, tends to use the resources of musical language to create in the combination of words and notes the drama of situation, context and mood.

Imitation can be both tonal and rhythmic and a good example of a rhythmic pattern that imitates movement described in the words can be found in bars 90 and 91. In the poem, Goethe breaks from the main metre and introduces an amphibrachic line with three internal rhymes: "Und wiegen und tanzen und singen dich ein" (Gloss: rock you and dance you and sing you to sleep). This rocking rhythm, a rhythmic anomaly in the poem, marks the end of the Erlking's cajoling phase and the start of a more sinister and threatening one. Schubert, recognising its importance, imitates the rocking gesture in musical terms, breaking from the main rhythm of the composition by having the left hand of the piano accompaniment change to reinforce the "rocking motion". Goethe's three internal rhymes and Schubert's lilting melody create an image of a rocking cradle and sound of a lullaby, increasing the irony of the "cradling" words that belie what the Erlking has in store for the child, death not sleep. When the symmetry of the line changes in the translation, the effect is lost. Of the three translations, only Garran's maintains the interplay between sound and words. Baker and Minchin evidently did not consider it essential, the lullaby effect is lost and so too the irony: 


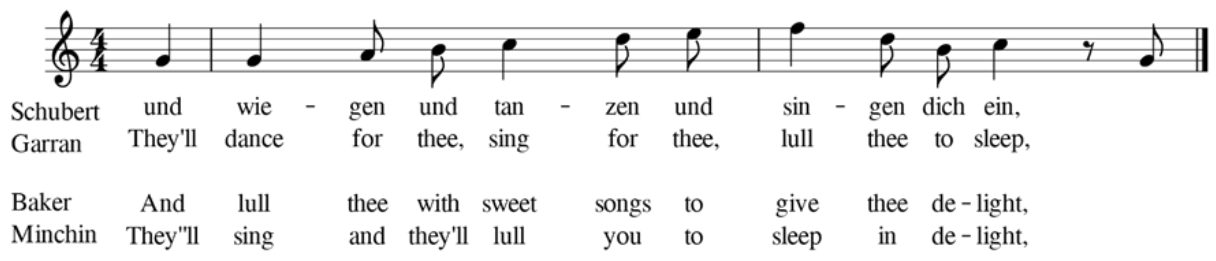

Figure 7. Franz Schubert, “Erlkönig” (D328), bars 89-91. Translations: Garran (1946: 133), Baker (Schubert 1895: 214-221), Minchin (1982: 40)

The use by the composer of different tonalities or keys and the way he modulates between them is an important part of word painting and dramatic composition. A change of key can denote a change of place, mood, atmosphere, action and so on. Different keys can be used to characterise different characters, psychologies, thoughts and behaviour. In Erlkönig, Schubert uses keys for character and psychology. The narrator opens and closes the story in G Minor. The father speaks mainly in major keys giving reassuring responses to allay the fear of the child although here and there he is dragged, as it were, into a minor modality. The frightened child always speaks in a minor tonality. The Erlking begins in major keys (B-flat, C and E-flat) as he attempts playfully to lure away the child, but eventually at the climax of the song, he chromatically modulates to D minor as he reveals his sinister intentions. Schubert, so to speak, physically demonstrates the Erlking taking hold of the child as the music of the Erlking's words merges with the minor tonality of those of the child.

Temporary changes of tonality can be equally if not more significant than a change of key, and chromaticism is frequently used by Schubert to underline yearning, to question or cast doubt on the words, or to bring about a sudden change in perspective. When a chromatic note or chord appears, the translator will be aware of some poignancy of emotion, perhaps some dissonance of feeling or meaning, possibly irony. In bars 116 to 120, for example, the Erlking shows his true colours and in a crescendo leaves his pleasant, cajoling major key of B-flat, in which he tried to cajole the boy away from the father, and turns instead to a straightforward threat in the D minor key of the child's tonal world. The chord on which "bist" (are) has been set is a diminished seventh chord that creates a distinctively tense and dramatic sound. The first syllable of "willig" (willing) has been set to another diminished seventh a semitone higher. After this there follows a perfect cadence in D minor for the words "so brauch' ich Gewalt" (then I'll use force): 


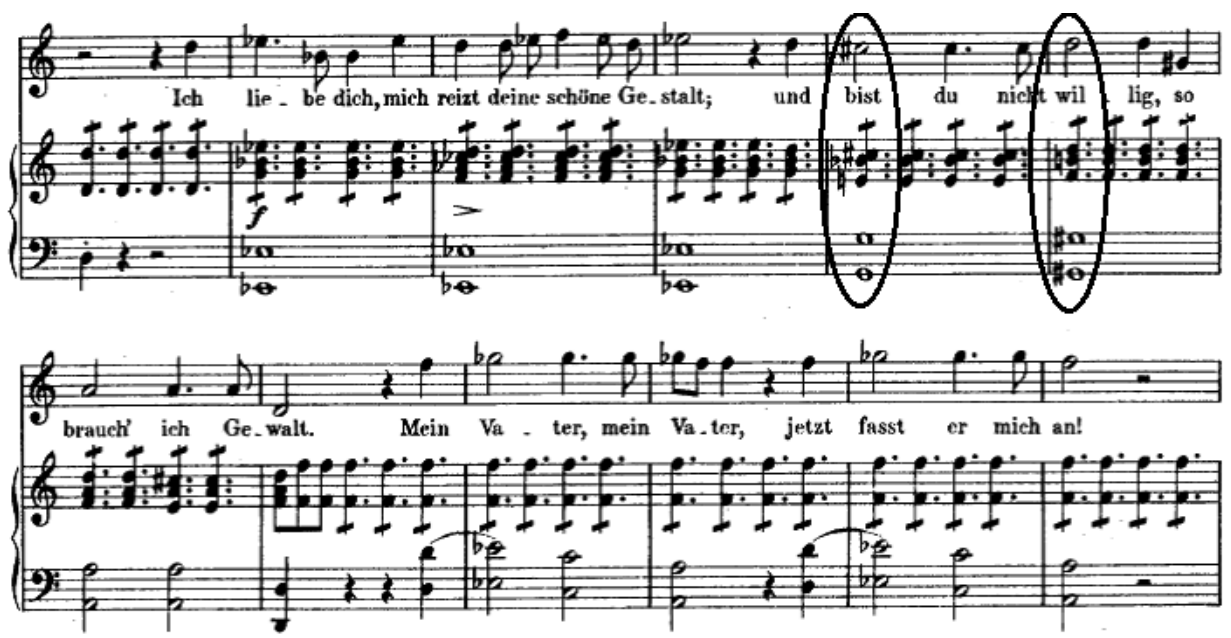

Figure 8. Franz Schubert, “Erlkönig” (D328), bars 113-124

Goethe's words "bist" (are), "willig (willing), "brauch" (use) and "Gewalt" (force) collocate closely with each other and are fused with the musical meaning in Schubert's emphatic and threatening diminished 220 seventh chords and the D minor cadence. The translations in English, do not re-produce the same verbal collocations and nor consequently the same relationship to the music. This is because in modern English if-conditionals are preferred to inverted conditional clauses. Even though Baker and Garran use archaic English throughout, in which the inverted conditional would have sounded quite at home, they chose to place the hypothetical conditional "if" on the first diminished seventh chord, rather than a verb that would collocate with the other three words as in the German. Of course, the listener can understand the relationship of the threatening sound of the chord and the coercion behind "if" and the translations (see below) and music work together well enough, yet the emphasis and threat of the first diminished seventh, its repetition and the connection between the words loses its impact.

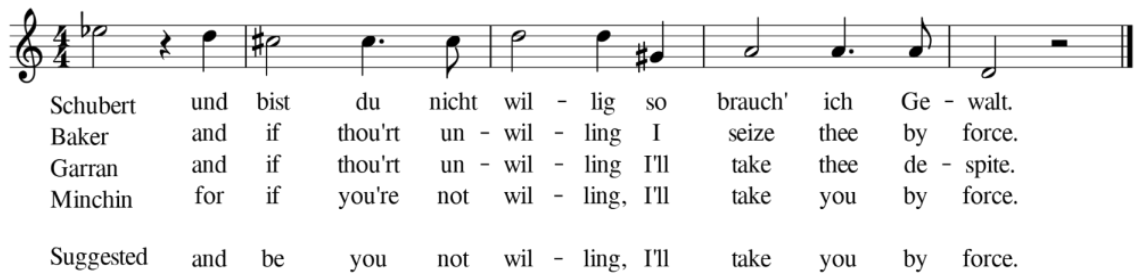

Figure 9. Franz Schubert, “Erlkönig” (D328), bars 113-124. Translations: Baker (Schubert 1895: 214-221), Garran (1946: 133), Minchin (1982: 40) 
Another prominent musical element that the translator may need to consider is the nature of cadences in relation to words: is there a feeling of incompleteness, which needs to be reflected in the words or is there an interrupted cadence that deceives the listener's expectations and leaves him or her wondering "what next"? For example, the boy twice asks the father if he can see or hear the Erlking. He does this on a chromatically rising line ending in an interrupted cadence, one that sounds like a question. The music is marked by dissonance and key modulation from major to minor, which re-creates in music the child's fear and desperate hope that his father is aware of the Erlking's threat. Therefore, when the question is translated as a statement, as Minchin does for the second question in bars 94-101, the fusion of words with music is lost and with it the multi-layered semantics of text and music:

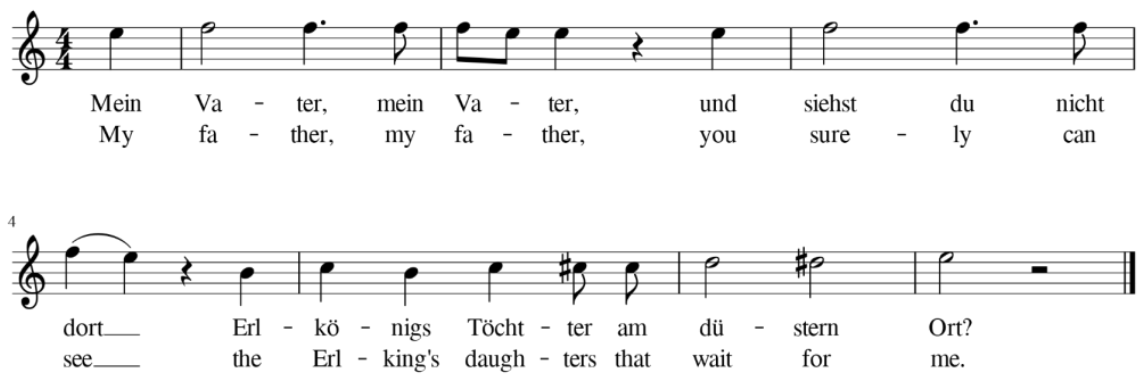

Figure 10. Franz Schubert, “Erlkönig” (D328), bars 94-101

The triadic nature of the song-sign is apparent in the match between verbal collocations in the poem and their musical setting. Goethe puts into the mouth of the Erlking words associated with glittering light, colour and fantasy that reflect the world to which he is attempting to lure the child, one that contrasts with the real world of the father, which is grey, dark, and drear. Schubert's music reflects this opposition in that the Erlking's music is initially deceptively playful and sweet and in major keys, whilst the father's music vacillates between major and minor tonalities and is measured and solemn. The signposts are there for the translator to reproduce the same effect in the translation but these are not always followed. For the line "Es scheinen die alten Weiden so grau. - ", two of the translators effectively interpret the word "scheinen" with its cognate "shine" and produce "The old willow gleaming grey by the mere" (Garran) and "This moonlight upon the grey willow tree" (Minchin). They have allowed the glittering language of the Erlking to cross over into the grey language of the father, thus ignoring the demarcation both 
verbally and musically between the two. It is not, however, necessary to translate "scheinen" with the obvious cognate or a synonym. "Scheinen" can also mean, "seem" or "appear" and Baker demonstrates that it is possible to avoid the crossover of realms: "[...] the form you see there/Is only the hollow grey willow tree"

Another similar example can be found in bars 63 to 70 where the otherworldly kingdom of the Erlking is given by Goethe in the line: "Manch" bunte Blumen sind an dem Strand" (Gloss: Many a colourful flower is on the seashore). Schubert has the Erlking sing this in a playful, seductive major melody contrasting the real-world surroundings predominantly presented in the preceding frantic rhythms of the galloping hooves motif and the minor tonalities and dissonances that represent theboy's experience of that world. The non-ordinary and non-expected language (Beaugrande 1978: 92) juxtaposed with Schubert's lyrical melody, which could easily lull one into a false sense of well-being, together contribute to the aural and semantic seduction by the Erlking. However, the otherworldliness found in Schubert is lost when Baker, Garran and Minchin translate the colourful flowers on the seashore as ordinary "varied blossoms" (Baker), "purple flowers" (Garran) or "gorgeous flowers" (Minchin) that grow on the "wold", an area of woodland on high ground, where one might normally expect bright flowers rather than on a beach. Something is lost when one of the parts of this intermodal fusion is altered without heed to the interaction between the modes.

Word-tone intersemiosis in a translation is perhaps more challenging than prosodic match or meeting the needs of the human voice and yet a translated song that has lost the poetic effect due to a lack of attention to the interplay of poetry and music, may never be sung. The singer may not find in it what $\mathrm{s} /$ he needs to interpret the song successfully for a performance. It seems to me, therefore, important that the interplay between verbal and musical meaning must be given serious consideration. ${ }^{7}$ Even when the translator, for linguistic reasons, is unable to replicate the original intersemiosis in every word and sound combination, his understanding of this can mean the difference between a translation that at least remains coherent with the original and cohesive within itself and one that does not.

${ }^{7}$ For an in-depth study of this approach to vocal music translation see WilsondeRoze 2017. 


\section{References}

Beaugrande, Robert de (1978). Factors in a Theory of Poetic Translating. Assen: Van Gorcum. Print.

Brown, Calvin (1948). Music and Literature: A Comparison of the Arts. Athens, GA: University of Georgia Press. Print.

Dahlhaus, Carl (1991). Nineteenth-Century Music. Trans. J. Bradford Robinson. Berkeley, CA: University of California. Print.

Garran, Robert Randolph (1946). Schubert and Schumann Songs and Translations. Melbourne: Melbourne University Press. Print.

Goethe, Johann Wolfgang von (1984). "Erlkönig". In: Willkomm und Abschied: Gedichte Des Jungen Goethe. Ed. Peter Fischer. (89ff). Berlin: Wagenbach. Print.

Gorlée, Dinda L. (1997). "Intercode Translation: Words and Music in Opera". Target 9 (2): 235-270. [accessed May 17, 2012].

Halliday, Michael A. K. (1978). Language as Social Semiotic: The Social Interpretation of Language and Meaning. London: Edward Arnold. Print.

Halliday, Michael A. K. (2004). “On Linguistic Aspects of Translation”. In: The Translation Studies Reader. Ed. Lawrence Venuti. (138-143). New York: Routledge. Print.

Jakobson, Roman (1960). "Linguistics and Poetics". In: Style in Language. Ed. Thomas A. Sebeok. Trans. Thomas Albert. Cambridge, Mass.: MIT. Print.

Kress, Gunther, and Theo van Leeuwen (1996). Reading Images: The Grammar of Visual Design. London: Routledge. Print.

Low, Peter (2005). "The Pentathlon Approach to Translating Songs". In: Song and Significance: Virtues and Vices of Vocal Translation. Amsterdam: Rodopi. Print.

Low, Peter (2008). "Translating Songs That Rhyme". Perspectives 16 (1-2): 1-20 [accessed Aug. 14, 2012].

Mayoral, Roberto, Dorothy Kelly, and Gallardo Natividad (1988). "'Concept of Constrained Translation. Non-Linguistic Perspectives of Translation"'. Meta 33 (3): 356-367. Print.

Minchin, Leslie (1982). Schubert in English. London: Thames Publishing. Print.

Mosley, David L. (1994). "Peirce's 'Ground' and 19 $9^{\text {th }}$ Century Lieder". In: Musical Signification: Essays in the Semiotic Theory and Analysis of Music. Ed. Eero Tarasti. Berlin: Mouton de Gruyter. Print.

Nida, Eugene (1964). Toward a Science of Translating: With Special Reference to Principles and Procedures Involved in Bible Translating. Leiden: Brill. Print.

O'Toole, Michael (1994). The Language of Displayed Art. London: Leicester University Press. Print.

Peirce, Charles S. (1931-1958). Collected Papers of C. S. Peirce. Ed. Charles Hartshore, Paul Wesis, and Arthur Burks. 8 vols. Cambridge, MA: Harvard University Press. Print.

Peyser, Herbert F. (1922). "Some Observations on Translation". The Musical Quarterly VIII (3): 353-371. 
Reiss, Katharina (1981). "Type, Kind and Individuality of Text in Translation". Poetics Today 2 (4): 121-131. Print.

Schubert, Franz (1815). Erlkönig G minor. Op. 1 D 328. Voice and piano 1815 music score.

Schubert, Franz (1895). First Vocal Album: For High Voice. Trans. Theodore Baker. New York: G. Schirmer. Print.

Snell-Hornby, Mary (2006). “Mary Snell-Hornby Excerpt from Translation Studies - An Integrated Approach". In: Translation: Theory and Practice: A Historical Reader. Eds. Daniel Weissbort and Astradur Eysteinsson. (443-451). Oxford: Oxford University Press. Print.

Stein, Deborah, and Robert Spillman (1996). Poetry into Song: Performance and Analysis of Lieder. Cary, NC, USA: Oxford University Press. Print.

Stein, Jack M. (1971). Poem and Music in the German Lied from Gluck to Hugo Wolf. Cambridge, Mass.: Harvard University Press. Print.

Wilson-deRoze, Karen (2017). Translating Wagner. A multimodal stylistic challenge. PhD Thesis. University of Leicester, UK. 